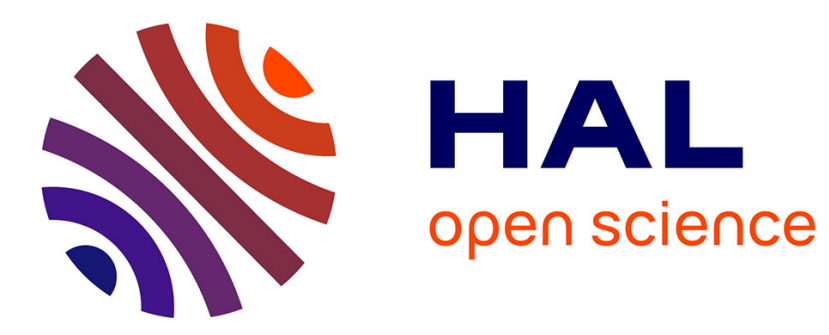

\title{
Rajin-Seonbong, new gateway of Northeast Asia
}

Jin-Cheol Jo, César Ducruet

\section{To cite this version:}

Jin-Cheol Jo, César Ducruet. Rajin-Seonbong, new gateway of Northeast Asia. Annals of Regional Science, 2007, 41 (4), pp.927-950. halshs-00458545

\section{HAL Id: halshs-00458545 https://shs.hal.science/halshs-00458545}

Submitted on 21 Feb 2010

HAL is a multi-disciplinary open access archive for the deposit and dissemination of scientific research documents, whether they are published or not. The documents may come from teaching and research institutions in France or abroad, or from public or private research centers.
L'archive ouverte pluridisciplinaire HAL, est destinée au dépôt et à la diffusion de documents scientifiques de niveau recherche, publiés ou non, émanant des établissements d'enseignement et de recherche français ou étrangers, des laboratoires publics ou privés. 


\title{
Rajin-Seonbong, New Gateway of Northeast Asia
}

Published in: Annals of Regional Science 41(4), 927-950

JIN CHEOL JO

Korea Research Institute for Human Settlements (KRIHS)

1591-6 Gwanyang-dong, Dongan-gu, Anyang-si, Gyeonggi-do 431-712, Republic of Korea

Tel. +82 (0) 31-380-0164 / Fax +82 (0) 31-380-0482 / E-mail: jincjo@krihs.re.kr

\section{CesAR DuCruet}

Erasmus University, School of Economics, Faculty of Applied Economics

Burg. Oudlaan 50, P.O. Box 1738, 3000DR Rotterdam, The Netherlands

Tel. +31 (0) 10-408-1678 / Fax +31 (0) 10-408-9141 / E-mail: ducruet@ few.eur.nl

\begin{abstract}
The economic zone of Rajin-Seonbong (Raseon) is located at the north-eastern border of North Korea, adjacent to China and Russia. Although its attractiveness to foreign investors has remained limited since its creation in 1991, Raseon is of growing interest as a transit port for Russian and Chinese trade. This paper reviews some theories on the constraints and advantages of remotely located ports, arguing that limited economic base can be overcome by a strategy based on transhipment flows to and from China, South Korea, Russia and Japan. In particular, it develops the idea that economic factors, such as remoteness from the nation's core region, are not sufficient to explain the uneven success of the project. More likely is the mismatch between local industries and port facilities. Unlike the Chinese free-trade zone experiment, port and logistics development in North Korea may take place prior to industrial development, strengthening Raseon as a potential gateway and growth pole in Northeast Asia. Keywords: DPRK; Free-trade zone; gateway; North Korea; port; Rajin-Seonbong
\end{abstract}




\section{INTRODUCTION}

Several reports and studies have addressed the economical and political changes in North Korea in the recent years, demonstrating very diverse opinions. Some authors depict the reform process as "underway and probably unstoppable" (Beal, 2004) while others think that many of the regime's economic changes and diplomatic manuvers "may prove self-defeating" in the long run (Sandhu, 2003) or see July 2002 reforms as a survival - rather than a development - strategy (Yoon, 2006). North Korea is still seen as a small country with no natural resources (Lee, 2002), although it hosts the world's major sources of magnesite and has enormous amounts of raw materials like minerals and metals, a very big advantage over its Asian neighbours. Furthermore, numerous works related to Northeast Asian logistics are also showing contradicting forecasts of interregional trade amounts passing through North Korea, with or without logistic improvement or Korean reunification. From Hunchen, China to Niigata, Japan, passing through Rajin port would lower 10 times the distance and 2 times the duration compared to Dalian port, while the voyage from Japan to Europe would be shortened by half and third in terms of distance and time respectively compared to the Atlantic route (The People's Korea, 1997a). The "new silk road" running east through Rajin would lower the delivery time and cost from South Korea to Europe by 50 percent and 30 percent respectively (Kovrigin, 2002). Not only for Chinese neighbouring provinces but also for Mongolia, securing sea access to the Pacific via North Korean ports is highly strategic and could reduce its dependence on Chinese or Russian transit ports (Batchimeg, 2006). In addition, the recent agreement of North Korea to end its nuclear development program in return of economic aid has accelerated the recognition of Rajin as a transit port. Russia is willing to connect Raseon's oil refinery to its Siberian oil and gas fields, while providing the zone with electricity through a joint development scheme, and China has confirmed its objective to link this Pacific gateway with adjacent Jilin province (Cargonews Asia, 2007). 
On the other hand, only a very few studies at the regional and local level show how contrasted the North Korean territory is, although complementary research on the development of Nampo, North Korea's main port and gateway to Pyongyang, has been recently provided (Jo and Ducruet, 2006). Still now, the country remains very closed to the outside world and "the lack of a comprehensive data-gathering structure using modern economic concepts and a systematic reporting mechanism make quantitative assessments difficult" (Nanto and Chanlett-Avery, 2005). Thus, it is difficult to get a detailed and recent picture of every main economic centre and province.

In this context, Rajin-Seonbong appears to be the most documented and controversial case of the current North Korean transition towards a market economy. However, "given the lack of detailed information about the internal decision-making process $(. .$.$) it is difficult to analyze"$ (Kim, 2001). Following the Joint-Operation Act of 1984 and the Foreign Investment Act of 1991, the Rajin-Seonbong Free-Trade Zone was established by the central government, directly attracting most of the US\$134 million of foreign direct investment (FDI) in the country (Park, 2004). In 2000, the city of Rajin and the county of Seonbong were merged to form the new administrative unit named "Raseon." Although it has not brought sudden openness to the entire North Korean economy (Noland and Flake, 1997), Raseon is the first capitalist experiment in the country's history, much inspired from the Chinese experience of Special Economic Zones.

The case of Raseon demands an updated outlook for several reasons. First, the usual argument of geographical remoteness as a constraint to foreign investment seems not to be sufficient, given the worse failure of Sinuiju Special Administrative Region, created in 2002 and based on its good connection to communication networks and its proximity to Chinese markets, for political reasons. Second, the North Korean economy and trade have improved since the reforms of July 2002, notably with its immediate neighbours: China, Russia and South Korea. 
Moreover, Chinese trade with North America is ever-growing and requires more direct access to the Pacific Ocean, to bypass the Yellow Sea ports. But also trade between China, South Korea, Japan, and even Europe (Rajin can be considered as a key nodal point at the end of the Trans-Siberian Railway), give this area a high strategic dimension for the entire region. Given such a perspective, the dispersed opinions must be clarified by looking at how port and industrial development are tied together. The Raseon case might be analysed as a case where political factors affect the simultaneous industrial and port growth depicted elsewhere in general (Takel, 1974) or in the specific context of a developing regional economy (Airriess, 1989). This is hinted by recent studies on Raseon, explaining its relative failure by political instability despite more favourable tax concessions than its neighbours, including Chinese zones (Nam and Radulescu, 2004). Furthermore, the argument in favour of a good connection of ports to their national hinterland seems not working for Raseon, which generates port throughputs without being connected by land transport to Pyongyang area, the core market of the country. Then, the limitations that usually cause port activity to decline can be overcome, by allowing Raseon to become one of China's gateways and, probably, one of Northeast Asia's main entry points, instead of being North Korea's gateway. Unlike the Chinese case of Shenzhen, were industries developed before ports thanks to the proximity of the already existing Hong Kong hub, port and logistic improvement in North Korea must happen before industrial development. By doing so, the FTZ project can get the recognition it failed to gain from foreign investors, at a time when factors of uncertainty combined dramatically with technical inadequacies and hampered the project.

In this respect, a number of questions need to be answered by referring to the previous literature on the relationship between ports and development. Since industrial location and central place theories related to North Korea have been discussed elsewhere (Lee, 2001), this paper proposes an overlook of Raseon through two other sets of theories: the spatial and 
functional development model of the "remote nodal gateway" (Stern and Hayuth, 1984), and a theory on the "lock-in effect" of centralized urban systems (Fujita and Mori, 1996). The interesting fact concerning Raseon, is its unconnectedness with its national core region, but its growing linkages with an external exporting area, the Chinese province of Jilin (Cotton, 1996a).

The first section of this paper reviews the theories on the economic development of remote ports. The second section addresses the background of Raseon FTZ in the context of North Korea's gradual opening to trade and foreign investment. Then, a third section focuses on the potential of Raseon in terms of labour supply, port infrastructure and trade activity with neighbouring countries, together with a specific analysis of cargo vessel movements between 1985 and 2005 at Rajin port. Finally, the last section addresses some policy implications about the possible future of Raseon as a new pole in Northeast Asia.

\section{ECONOMIC DEVELOPMENT AT REMOTELY LOCATED PORTS}

General characteristics of port nodes

Although it is true that ports, like any other transport infrastructure, may encourage economic development, through agglomeration and scale economies (Bird, 1977), the growing complexity of transport players' strategies has dramatically questioned the systematic relationship between port activity, local economy and hinterland proximity, due to other factors such as port competition and land-sea accessibility (Notteboom and Rodrigue, 2005). Furthermore, the level of traffic “is, at least in part, a reflection of the quality of the city's location." It combines the two dimensions of centrality - the hub city's own traffic-generation power that comes from its size and function as well as its location - and intermediacy - extra activity levels conveyed to the hub by the carrier's choice of this location for operational geographical emphasis within their transportation systems (Fleming and Hayuth, 1994). It 
means that a port, for example, can induce traffic despite the absence of a hinterland and local industry, if transport players decide to include this location in their network to facilitate shipping between other trading regions or even other ports. Among the different types of port cities synthesized by Ducruet (2004) in the port-city matrix, gateways and hubs have in common a higher intermediacy (Figure 1). Gateways are subdued to remote markets and develop few activities apart from heavy industry and logistics (e.g. Le Havre, Genoa, Rotterdam), while hubs are dominated by transport functions (e.g. Gioia Tauro, Freeport, Salalah), and outports are gateways of close cities (e.g. Bremerhaven / Bremen, Belawan / Medan, Sepetiba / Rio de Janeiro). Those three types have in common a strong intermediacy but a limited centrality.

\section{[INSERT FIGURE 1 ABOUT HERE]}

The distance to core regions

Two sets of theories help to balance the simple effect of distance on the developmental effects of ports. First, the geopolitically located port model defined by Stern and Hayuth (1984) as a port isolated and remote from the population and economic centres of its country. Compared to a conventional port system, such a port develops in four stages, based on the cases of Aqaba (Jordan) and Eilat (Israel):

- remote nodal gateway: serving directly and only the national economic core restricts the activity to the port function, without leading to any development effects on the port city and its vicinity, nor to any emergence of a proper hinterland;

- functional gateway: market expansion at the economic core and its immediate periphery, but the gateway remains unaffected despite the growth of cargo; 
- transit gateway: national strategy of profit-maximisation and diversification of traffics due to the inclusion of in-transit cargo shipments, turning the relationship between the core and the gateway into a two-way linkage;

- integrated transhipment system: improvement of transport between core and gateway (e.g., intermodal links), but the latter still suffers from remoteness and the lack of human resources. Only limited intra-urban activity growth is observed, with very few peripheral effects on the gateway's surroundings.

The details of Rajin-Seonbong indicate that it would correspond to such a case, given its remoteness and its limited urban and industrial growth in the last decades. However, a main difference with the model is the lack of relation between the Pyongyang capital region and Raseon (Figure 2). Rail transport would take two or three days between the two areas, and road transport is almost unthinkable given the poor transport conditions, in a country where 93 percent of roads are unpaved (Bang, 2004). The mountainous barrier between East and West is only overcome by railways, the dominant transport mode of the country (Oh, 2001) since logistics costs hamper truck voyages (Roussin and Ducruet, 2006). While remoteness from Pyongyang can be seen as both economically negative and politically positive for the zone (Kim, 2001), former studies have neglected the role of intermediacy among macroregional factors. Furthermore, distance to bigger ports and trading regions is not a constraint but an advantage in the strategy of developing transhipment or load centre functions, as in the challenge of peripheral ports depicted by Hayuth (1981).

[INSERT FIGURE 2 ABOUT HERE] 
In a more developed but comparable environment, the Baltic ports attempt to overcome their remoteness to European core regions by catching transit trade with Russia. For example, recent figures show that Riga, Latvia, has seen its share of Russian transhipment cargo among total cargo rising from 10 percent in 1991 to 40 percent in 1995 and 50 percent in 1996 . The same phenomenon happened in Tallinn, Estonia, with a share of 45 percent in 1995 and 70 percent in 1996, and has been slighter in Klaipeda, Lithuania, as the share stagnated around 20 percent of the port's total throughput (Thorez, 1998). Such trends can be explained by the need for Baltic port cities to diversify their traffics, to bypass the limitations of inland transport systems and to find external forces that can be an engine to induce local economic development. As a result, most industrial parks in the Baltic States have been created around port areas like Ventspils, Liepaja, Riga, Tallinn and Klaipeda.

Fujita and Mori (1996) note that "in many developing countries (such as Indonesia and Thailand), although their governments have striven to decentralize industry to the periphery, the lock-in effect of existing primate cities (which are mostly port cities) has been so strong that their efforts have been unsuccessful." In particular, the authors indicate that the improvement of transport connections between the centre (i.e., Pyongyang) and the periphery (i.e., Raseon) may be harmful to the industrial development of the latter, especially if the remote port city has not developed any specific and competitive industry. Raseon stands far behind other ports in terms of proximity to mines and natural resources, apart from the largest coal field of the country, which occupies almost 50 percent of North Hamgyeong province (Wu, 2004). Only the worsening of the transport connection might allow the peripheral port to develop thanks to "self-reinforcing agglomeration economies." Pyongyang is not a port but a continental core connected to the sea only by the Daedong River, where navigation is limited to small barges carrying raw bulky products like sand. In this respect, the absence of sufficient linkages between the core and the periphery may help ports, as in such perspective "the 
advantages of water-transport (...) shift the larger cities from the centre of the region to points on the periphery" (Smolensky and Ratajczak, 1965).

\section{ADVANTAGES AND CONSTRAINTS OF RASEON FTZ}

\section{Background and economic performance}

The Free Economic and Trade Zone of Rajin-Seonbong was planned by the $74^{\text {th }}$ decision of the Administration Council of North Korea on 28 December, 1991. Because independence and self-suffiency were not inconsistent with foreign trade, the former leader Kim Il-Seong chose Rajin-Seonbong as a first experiment of an open door policy (Cotton, 1996b). Motivation from the central government was based on the inefficiency of its own economic strategies and production system, the shortage of foreign currency, the successful experience of China and the sudden isolation provoked by the disruption of trade with the former Soviet Union in the late 1980s (Nam and Radulescu, 2004). Rajin-Seonbong also appears as a key element of the Tumen River Project from the United Nations Development Program (UNDP), which aims at enhancing regional cooperation between neighbouring states and provinces. Covering 746 sq m since its enlargement in 1993, it is one of the planned 'growth centres' with the Russian port of Posyet and the Chinese open city of Hunchen. In this context, "the DPRK is the most avid proponent of [the project] since they are unwilling to cede any of their territory to an internationally managed zone" (Marton et al., 1995).

It has been reported that among the 113 registered companies in 1998 operating in the zone, 67 remained in 2000 of which 20 were Japanese. The total FDI flows (see Table 1) reached an amount of \$US 88 million in 1998, accounting for almost 9 percent of the total investment in the Tumen River Area (excluding Mongolia). Despite the Asian financial crisis, which apparently affected Chinese and Russian FDI flows, Raseon has increased its share since 1997. However by 1999, the amount of FDI represented only 10 percent of the original 
contract, mostly from China, Hong Kong and Japan (Lee, 2002). Other indicators in Table 1 all point at the sudden increase in GDP and trade since 1999. However, this trend is not well reflected by official port statistics in which traffics are rather stagnating along the period. There is no equivalent evolution of trade volumes and port traffics. Two reasons are proposed: the landward character of trade, and the little adequacy between port functions and local industries. The dominance of China and of imports shows that instead of using the port as a catalyser, major developments in Raseon are more likely to be oriented towards China itself through road and rail transport. This is hinted by local observers which consider inland container traffic - 3,000 boxes in 1997 - with neighboring cities (e.g. Hunchen, Tumen) as crucial (The People's Korea, 1997b). In addition, China applies preferential treatment: "products that were processed in the Rajin area with Chinese materials and then imported to China, for instance, were labelled domestic trade and were thus exempted from customs inspection" (Kim, 2006).

In terms of port capacity, the port of Rajin is ranging from 3 to 3.5 million tons of trade, but its current throughput is said to be less than 10 percent of its capacity (Tumen River Area Development Programme, 2006). Despite a limited activity, Raseon is well equipped on a national level in terms of port infrastructure and capacity. However, the specialisation of Rajin port, based on coals, fertilizers, timber, and sundries is not well matched with a local economy focused on seafood, food processing, construction, real estate, tourism, and transport, since the economic zone has been launched. Available information on Rajin and Seonbong ports much reflect the pre-Raseon period defined by the priority to heavy industries and bulk products, which is reflected in the poor level of cargo handling facilities. Seonbong port is more specialised in petrochemical products and crude oil imports, with $3.2 \mathrm{~km}$-long undersea pipelines connected to Seungri Chemical Co., Seonbong Thermal Power Plant and a floating oil dock (Asia Trade Hub, 2006). Seonbong's economy is also much linked to energy, 
with uranium mine and a 200-megawatt oil-fired power plant, an oil refinery and an electric power plant. In fact, transit trade has been dominant at Raseon ports since the 1960s, handling Russian cargoes from Vladivostok and Nakhodka to Japan and Southeast Asia, such as fertilizers, marine products, and redirecting steel pipes, general cargoes and raw aluminium materials from Japan, Australia to Russia (Han, 2006). This may explain why the local economy has little to do with traditional port activities. Conversely, most recent investments show the weak linkages between local industries and the port (Table 2), as already stated by UN official Ian Davies, head of the Tumen project: "we would have liked to have seen more contracts signed in the manufacturing sector" (Lee, 1996). This is confirmed by Kim (2006) that "the sectors in which China invested have heretofore focused on service" although more attention has been recently drawn upon manufacturing, mining, and energy. Among the industries in Raseon that may use the port for exporting their products, most are concerned with small cargo volumes (e.g. fish and marine products), while other industries are mostly services and retail.

\section{[INSERT TABLE 2 ABOUT HERE]}

\section{Spatial constraints at local and national levels}

Next table gives a synthesis of the urban and port characteristics of the two local units, Rajin and Seonbong (Table 3). Figures are collected from a vast amount of different publications but the housing units have been counted by the authors from a geographical atlas. Such a synthesis allows understanding the potentials and relative importance of Raseon.

[INSERT TABLE 3 ABOUT HERE] 
When comparing the two profiles of Rajin and Seonbong according to housing capacity, it appears that the status of Rajin as a city is reflected in the higher proportion of high density housing, and the number of rural-type units are higher for Seonbong. Thus, the urban centre of Raseon is Rajin itself. Furthermore, the settlement pattern of the two city-regions shows that Rajin, with 95 percent of housing units in the core area, is much more compact than Seonbong, which has only 77 percent. It is partly an effect of the site, because Rajin is much more constrained than Seonbong.

Thus, the potential sites for the expansion of port and industrial facilities are scarce in Rajin and quite important in Seonbong (Figure 3), as indicated in Table 3. The advantage however is that the most important sites for industrial development are located on both sides of the tunnel, close to the satellite neighbourhood of Unjakgu (Rajin) and the district of Namgwandong (Seonbong), what can facilitate the communication and interaction between the two locations. Then, the tunnel itself should be maintained and secured for regular truck transport.

\section{[INSERT FIGURE 3 ABOUT HERE]}

In addition, Raseon's share of population among other North Korean port cities is relatively low, due to the very limited natural growth and strong institutional control of in-migrations (Figure 4). Population figures are difficult to interpret in North Korea due to the very controlled dimension of migration and transportation, and to the recent famines that lowered population considerably, especially in areas remote from Pyongyang. As it is a border area and a port, Raseon is highly strategic and the North Korean government and the army might have reduced to a minimum the working population in the area, and constrained the "natural" effect of the gateway's self-agglomeration (e.g. rural exodus). On a national scale, the closest 
cities to Pyongyang, namely Nampo and Songrim, which are also ports, enjoyed the highest demographic growth, and closely followed by the port city of Haeju and the city of Sariwon. Away from the capital region, only the city of Sinuiju and the port city of Cheongjin show important growth during that period. Rajin remains a small coastal town where the FTZ project and the port activity still haven't been able to enhance the city size and functions, or act as a growth pole.

[INSERT FIGURE 4 ABOUT HERE]

One should not forget a wider phenomenon affecting the whole country. Most urban centres in North Korea have suffered from the decline in production from $60 \%$ of the economy in 1987 to $27 \%$ in 2002, and from the reduction of the factories' industrial capacity around 2030\%. Domestic transport activity concentrates the most in South Pyongan (30\%), North Hamgyeong of which Raseon (24\%), South Hamgyeong (17\%) and North Pyongan (10\%) provinces, and $80 \%$ of North Korea's exports pass through Sinuiju at the border with China (Tsuji, 2005). In fact, freight transport activity in North Korea is concentrated in the major port regions of the country: the Nampo-Pyongyang corridor (South Pyeongan) and the Raseon-Cheongjin area (North Hamgyeong).

As a result, Raseon is North Korea's most dependent area on port activity and maritime trade, according to the relative concentration index used by Ducruet and Lee (2006) on the world's port cities. The index is calculated as follows: the percentage of foreign trade divided by the percentage of population among the total of the port cities. It shows the relative situation of port cities in both urban and port systems. Nampo, Haeju, Cheongjin, and Heungnam have a balanced profile (values close to ' 1 '), Songrim and Wonsan have a lower port function (values 
under ' 1 '), and Raseon is comparatively an unusual case, with the enormous importance of port functions compared to other functions.

\section{A synthesis of pros and cons}

In both comparison tables of Kim (2000) and Lee (2001) about the characteristics of possible investment areas in North Korea, Raseon is ranked seventh among eight. Transportation, agglomeration effect and labour quantity were described as the limiting factors while raw material provision is the only factor exceeding average scores. Again, explanations are funded on deterministic factors such as remoteness and altitude.

Table 4 shows a synthesis of the factors explaining the current state of Raseon's economy. Its natural conditions are favourable, and its location fits the profile of a transit port (or transhipment port) using other neighbouring countries' freight for its own activity. Raseon is not limited by railway standards, and the quality of roads is currently being improved for trucking with Hunchen, China. A new logistics-free zone is under way at Namyang (Rank, 2006), following rail access improvements with the electrification of $168 \mathrm{~km}$ of tracks, and the construction of a marshalling yard for handling containers to and from the zone as $70 \%$ of its traffic is made by trains (Kim, 2001). The advantages provided by the FTZ seem not to be in accordance with the quality of existing industries, and it would have needed considerable effort to improve them or to create new industrial sites. In a recessive context, combined with a highly competitive environment in Asia, investors have preferred to locate in other export platforms offering even slightly higher wages or lower incentives, but where the infrastructure and industrial facilities are operational. For Raseon, the gap between the means and the objective has been the main barrier to its success (Asian Political News, 2001). Remoteness is a minor factor which can be easily overcome in an age of global logistics. As stated by Kim (2001), the combination of negative factors has turned potential investors away from the zone 
to the alternative destinations of Hunchen and Primorsky. A look at available statistics is thus necessary to help understanding how port functions are likely to improve Raseon's status as a gateway.

[INSERT TABLE 4 ABOUT HERE]

\section{STRATEGIES FOR RASEON AS A NORTHEAST ASIAN GATEWAY}

\section{Trade evolution and port activities}

The general foreign trade pattern of North Korea (Table 5) clearly indicates the growth of the relationships with China, which has reached a dominant share (39 percent), far beyond South Korea (26 percent). This is a positive trend for Raseon, together with the trade with Russia, which has doubled between 2001 and 2004, and slightly decreased then.

\section{[INSERT TABLE 5 ABOUT HERE]}

Unfortunately, there is not much information available about Raseon's detailed trade activity and share in the trade with China. Trade figures between North Hamgyeong province and China show a growth and decline in tremendous proportions: from $3.7 \%$ to $21.6 \%$ and to 4.8\%. The impact of Raseon has fallen short in enhancing DPRK trade, which is more likely to originate from other areas of the country. Although it does not distinguish between North Pyongan (Sinuiju) and North Hamgyeong, border trade with China has grown up regularly since 2003: $6.3 \%, 8.4 \%$ and $10.9 \%$ of total DPRK trade respectively. Jilin province is ranking behind Liaoning - border trade with Sinuiju - for North Korean exports since 2001, but its share in North Korean imports is slightly higher and more regular. North Hamgyeong province may have become an import area rather than an export area in the recent years. 
The modal distribution of trade volumes to and from Raseon or North Hamgyeong province is not known. Little information exists about the main sea routes linked to Rajin port but detailed traffic statistics remains very scarce. Since 1995, it was reported that a shipping line was moving Chinese containerised cargo abroad through Rajin, as well as some fertiliser brought by rail from Russia, using a multipurpose terminal. Chinese interests are also reflected in the leasing of Rajin's second pier to China for 80 years (Ming, 2003). But still, the regular shipping route established in 1999 with the Japanese port of Akita is "dormant [and has] only irregular services, mainly due to a lack of cargo" (Tsuji, 2003). Nevertheless, maritime trade between Rajin and Busan, South Korea, has continued since the opening of this route in 1995 , with 4,000 to 5,000 TEUs $^{1}$ of cargo being handled annually, but it competes with the neighbouring ferry service between Sokcho, South Korea, and Zarubino, Russia. As a result, if the number of containers handled at Rajin port is far below the capacity of 30,000, container throughput is constantly increasing: 2,867 in 1996, 3,161 in 1997 and 2,828 in the first half of 1998 for the most recent figures available (The People's Korea, 1998). However, any data provided by official announcements should be cautiously used. Unrealistic figures depicting the 300 million tons capacity of the port since 2000 with the 17 quay cranes (Han, 2006), and the creation of a 30,000 TEUs capacity resulting from foreign investment (Korean Central News Agency, 1998) have not yet been proved.

More accurate data can be obtained from the Ministry of Unification in South Korea, but it is limited to North-South trade and only for some years. As shown in Figure 5, Rajin has the highest share of north to south trade ( 80 percent). It means that it is the port where shipments from the south, mostly humanitarian, are the lowest, because of a limited population, and thus indicates that Rajin's function within Korean trade is to handle transhipment cargo from other countries to South Korea. Other ports having the same profile only handle limited cargoes.

\footnotetext{
${ }^{1}$ Twenty-foot Equivalent Unit, standard measure of container throughput
} 
This pattern, although it is susceptible to change every year, gives some clue about the function of the ports in the national and regional economy. Conversely, the dominance of south-north shipments indicates that these ports are importing goods for their local and regional economy, and are located close to industrial areas and urban settlements (e.g., Nampo, Songrim, Haeju, Heungnam, Sinpo, Cheongjin), with the exception of Seonbong, which is used for oil imports. Thus, Rajin's profile appears to be more extraverted, fitting the definition of the remote gateway: a dominant transhipment function and a relative absence of proper industries. Although data about the type of goods which have been shipped from Rajin to Busan and Ulsan are lacking, one can extrapolate that goods are mostly of Chinese and Russian origin, because of the limited industrial base of Raseon. This can be partly solved by looking at the types and capacities of the cargo vessels calling at Rajin in the last two decades.

[INSERT FIGURE 5 ABOUT HERE]

\section{Cargo vessel traffics in Northeast Asia}

Although they do not perfectly illustrate the real amount of tons handled at Rajin port, data on cargo vessels provided by Lloyd's, a leading maritime insurance company registering approximately $80 \%$ of the world's fleet, allow a good overview of the different trends affecting the gateway (Table 6). Ship capacities in deadweight tons (DWT) have been summed on a yearly basis and distributed according to the type, volume, origin and destination of the cargoes.

[INSERT TABLE 6 ABOUT HERE] 
At first glance, Rajin has never been a leading port in North Korea. Its relative capacity on a national scale has only exceeded $7 \%$ during the three years following the operation of RajinSeonbong FTZ (1992-1994). After a period of decline, it is only since 2003 that the relative weight of Rajin has gone back to its original level of the mid-1980s: around 3\%, although absolute figures remain lower.

The question is to evaluate which of the two following factors underlie traffic variations: uneven success of the FTZ itself or wider political trends such as transition between two presidencies. In a more opened environment such as transition or new industrialized countries, traffic growth would have been sustained due to the absence of major obstacles once the economic zone is launched. Technical and logistics factors would improve gradually after the first investments. In the case of Raseon and DPRK, 1994 might not only mean the loss of investors due to persisting local difficulties, but the political crisis after the death of former president Kim Il-Sung. During the three following years, his son Kim Jeong-Il has fought hard against the army and the cabinet in order to gain recognition. Not only this difficult transition has affected ongoing projects such as Rajin-Seonbong, but it has been worsened by other priorities due to nuclear crisis, floods, and famines between 1994 and 1996.

Before 1991, traffics are dominantly general cargoes, but it seems that the operation of the FTZ has necessitated importing large amounts of solid bulks (e.g. cements, construction materials) in order to realize the project. Since 1995, traffics have gone back to the dominance in general cargoes. Although they have existed between 1988 and 1990, conventional cargoes have really increased since 2004, as a possible illustration of the realization of Chinese transit trade. However, Chinese trade is land-based and can only be reflected indirectly by the figures. Container traffics measured in twenty-foot equivalent units (TEUs) also show the sudden drop since 1994, which has not yet been recovered. 
Another important feature of Rajin's traffics is the decreasing size of ships since 1994. Thus, most cargoes are being shipped on the smallest vessels (i.e. less than 4,500 tons). It undoubtedly reflects the deterioration of port infrastructures combined to the decrease of regular shipping lines. More likely are irregular and small shipments in the recent years. Such evidence seriously infirm official announcements about the 200,000 tons vessels to be accommodated of which 36 could be berthed at the same time (Korean News, 1997).

The geographical distribution of the traffics (Figure 6) essentially shows the disappearance of Chinese maritime trade with Rajin since 1997, and the recent increase of traffics with Russia, at the expense of Japanese cargoes. The first years of FTZ (1991-1994) illustrate the greater diversity of partners, with South Korea and Southeast Asian countries such as Singapore, which have not been much connected to Rajin port before and after this period. As shown in the map, the regional foreland of Rajin port has constantly retracted from one period to another. Most traffic is realized to and from closest ports (Japan, Russia) while other Chinese ports, Hong Kong, and also Singapore have dramatically reduced.

\section{[INSERT FIGURE 6 ABOUT HERE]}

\section{SYNTHESIS AND CONCLUDING REMARKS}

Despite the scarcity of data, it has been possible to estimate the role of Raseon in North Korean and North-South trade and transportation. In terms of industrial outputs, the economy of Raseon has not been able to cope with the needs of foreign investors, in a context of tense relationships with neighbours, especially after the succession of Kim Il-Seong and the increase of ideological and military concerns. This paper has attempted to clarify the limiting factors affecting the development of a free trade zone in a constrained economy. It argues that 
the demise of the project is explained by a combination of functional and political factors rather than by the inherent demerits of the zone or its remoteness to core economic areas.

Functional factors refer to local linkages between different activities. The evolution of port traffics reveals that Rajin port has mostly been used for starting the project in the early 1990s, but since then traffics have been stagnant and irregular. While this is seen as a result of technical lacks of port infrastructures and handling facilities, we argue that the main reason is the weak functional linkages between the free trade zone and the port. Investors and planners have not seen the port as a catalyser for their development. Tax exemption has been the main reason to invest in the zone, regardless of a long-term strategy. Thus the port, although it was not yet perfectly adapted to global technical standards in the early 1990s, could have enhanced trade growth and long distance connections if more manufacturing companies were settled there, like in other developing countries. However, due to this mismatch between service activities (e.g. hotels, casino, and telecommunications) and the port, the latter has not been able to act as an engine for industrial development. Its role has remained limited to secondary activities such as seafood exports.

Political factors concern the relationship between investors and North Korean officials. Investors would not have been suddenly discouraged after a few years of operation since basic requirements were provided. In fact, the sudden disrupts since 1994 shows that urgent political and first aid matters have taken precedence over the capitalist experiment. It has become rapidly more difficult to restart the project on growingly unstable grounds and ageing infrastructures. It definitely depreciates the deterministic argument on the low economic profitability due to accessibility and connectedness. Moreover, ten years after the creation of the Rajin-Seonbong FTZ, the demise of Sinuiju SAR proved that the remoteness of Raseon was not the main factor limiting its development. Although Raseon hasn't emerged yet as an industrial growth pole, its port activity has been steady despite the absence of a hinterland and 
a local economic base. At the end, Raseon's role is better described as a connecting point between regional economies, rather than a gateway for its own province and country. Regarding Stern and Hayuth's model of the remote gateway, Raseon surely matches with the developmental stages described: limited effects of port activity on the local and regional economy, and growth of transit trade to serve outlying regions rather than its own hinterland, which is absent or limited to one type of material (coal). However, the model does not match the case of Raseon entirely because the main region served is not the core region of the country. Then, Raseon is not the gateway of North Korea (or Pyongyang) but the gateway of Far-East regions, competing with Russian ports to serve East Sea and Pacific trade. Such a situation can be compared to some Baltic ports like Tallinn, Riga and Klaipeda, whose activity is mostly coming from Russian transit trade to and from Western Europe, due to inland freight constraints and a limited national market in a context of transition (Brodin, 2003).

Regarding Fujita and Mori's theory of the lock-in effect of urban systems on port cities, it appears that the distance to Pyongyang and the very limited connectedness between Pyongyang and Raseon did not produce self-agglomeration effects in terms of demographic and economic growth. Here, political factors are crucial and have constrained the development of the FTZ, despite the efforts to implement a capitalist enclave at a time when even economic reforms were still unthinkable. Thus, the continuous growth of Raseon's port and logistic function seems to be the only way to make this place attractive to foreign investment, and the vision of Raseon as a growth pole resulting from FTZ incentives should be left aside in a first stage.

Looking back in time, the FTZ project should have been less ambitious and focused on pure logistics instead of aiming at creating a favourable business environment without much evidence of the place's ability to trade. One should notice that up to 1998, hotel business and 
tourism occupied 35\% of Raseon's FDI, but the casino has since been deserted by its Chinese customers. By basing its development on the port function, Raseon could follow the "traditional" port city evolution, with a gradually diversification of its economy, from a port city to an industrial city and to a general city (Murphey, 1989). Such process may not be hampered by competition from neighbouring Cheongjin, a bigger port city, given the recent observations about its dramatic situation ${ }^{2}$. However, in a constrained country like North Korea, where political factors are critical and complex, the provision of a free-trade environment is not sufficient. In particular, the success of the Gaeseong Industrial Complex, close to the South Korean border, can be explained by lesser military concerns - Gaeseong is an inland city, not a port - and by the direct involvement of South Korean public and private players in implementing the zone. For the Shenzhen case in China, the role of Hong Kong has been crucial to the success of the zone for other foreign investors, in terms of technology transfer and logistic improvement. For Raseon, Pyongyang is still not able to induce such development from inside. Thus, the strategy based on Chinese transhipment and, further, Northeast Asian transit trade appears to turn the remoteness of Raseon into an advantage. Not only it is the only advantage of Raseon, until North Korean development itself reaches further stages, but also its status as a free port enjoying good natural conditions strengthens its intermediacy - and thus, competitiveness - in assuming a gateway function. For Raseon, only a regular and growing trade can provide a fertile ground for further economic growth, by bringing back the confidence of foreign investors to the FTZ itself.

\footnotetext{
${ }^{2}$ As observed by UN official Tun Myat in 1997: "Chongjin was like a forest of scrap metal, with huge plants that seem to go on for miles and miles that have been turned into rust buckets. I've been all over the world, and I've never seen anything quite like this".
} 


\section{REFERENCES}

Airriess C A (1989) The spatial spread of container transport in a developing regional economy: North Sumatra, Indonesia. Transportation Research A: General 23: 453-461.

Asia Trade Hub (2006) Present status of North Korea's 8 major trade ports. http://www.asiatradehub.com/n.korea/ports.asp

Asian Political News (2001) N. Korea's special economic zone remains in doldrums. July $2^{\text {nd }}$.

Bang H K (2004) Research notes: towards an integrated logistics system in Northeast Asia. East Asian Review 16: 111-121.

Batchimeg M (2006) Mongolia’s DPRK policy. Asian Survey 46: 275-297.

Beal T (2004) Pyongyang goes to market: marketization of the North Korean economy. Discussion Paper, Victoria University of Wellington, New Zealand.

Bird J (1977) Centrality and Cities. Routledge Direct Editions, London.

Brodin A (2003) Baltic ports and Russian foreign trade, studies in the economic and political geography of transition. University of Gothenburg, Department of Human and Economic Geography, Series B, n $^{\circ} 104$.

Cargonews Asia (2007) Russia, China vie for control of North Korean port. March $6^{\text {th }}$.

Cotton J (1996a) China and Tumen river cooperation: Jilin's coastal development strategy. Asian Survey 36: 1086-1101.

Cotton J (1996b) The Rajin-Sonbong free trade zone experiment: North Korea in pursuit of new international linkages. Working Paper $n^{\circ}$ 9, Australia National University, Research School of Pacific and Asian Studies, Department of International Relations, Canberra. 
Cotton J (1998) A radical experiment: the evidence is in from North Korea's Rajin-Sonbong area. Harvard Asia Pacific Review 2: 57-60.

Ducruet C (2004) Port Cities, Laboratories of Globalization. Unpublished PhD in Geography, Le Havre University, France.

Ducruet C and Lee S W (2006) Frontline soldiers of globalization: Port-city evolution and regional competition. Geojournal 67(2): 107-122.

Dunqiu L (2006) Economic and social implications of China-DPRK border trade for China's northeast. Proceedings of the National Bureau of Asian Research Conference on Regional Economic Implications of DPRK Security Behavior, Beijing, January 18-19.

Fleming D and Hayuth Y (1994) Spatial characteristics of transportation hubs: centrality and intermediacy. Journal of Transport Geography 2: 3-18.

Fujita M and Mori T (1996) The role of ports in the making of major cities: selfagglomeration and hub effect. Journal of Development Economics 49: 93-120.

Han Y J (2006) NK-China 50 years joint development launched, Rajin port draws attention. Daily NK, March $24^{\text {th }}$.

Hayuth Y (1981) Containerization and the load center concept. Economic Geography 57: $160-176$.

Helders S (2006) The World Gazetteer. http://www.world-gazetteer.com/home.htm Jo J C and Adler S (2002) North Korean planning: urban change and regional balance. Cities 19: 205-215.

Jo J C and Ducruet C (2006) Maritime trade and port evolution in a socialist developing country: Nampo, gateway of North Korea. The Korea Spatial Planning Review 51: 3-24. 
Kim C K (2000) Strategies for investing in North Korea, pp. 10-13 in: VIP Millenium Report, Hyundai Research Institute, Seoul.

Kim I S (2001) The Rajin-Sonbong economic and trade zone (RSETZ): the sources of difficulties and lessons for the future, pp. 301-333 in: Yoon, C H and Lau, L J (Eds.), North Korea in Transition, Edward Elgar, Cheltenham and Northampton.

Kim J C (2006) The political economy of Chinese investment in North Korea. Asian Survey 46: 898-916.

Korean Central News Agency (1997) Rajin port - free trade port. March $12^{\text {th }}$. http://www.kcna.co.jp/item/1997/9703/news3/12.htm

Korean Central News Agency (1998) Transport system in Rajin-Sonbong zone. July $9^{\text {th }}$. http://www.kcna.co.jp/item/1998/9807/news07/09.htm

Kovrigin E B (2002) The Russian federation and the two Korean states: economic cooperation in the early $21^{\text {st }}$ century. The Cooperation between Korea and Europe, Korea Trade Research Association International Conference, October $25^{\text {th }}$, Seoul, Korea.

Lee W R (1996) Rajin-Sonbong Free Economic Trade Zone on Track. Korea Web Weekly, September $17^{\text {th }}$. http://www.kimsoft.com/korea/nk-raj3.htm

Lee D H (2001) Industrial location planning in North Korea, pp. 269-300 in: Yoon, C H and Lau, L J (Eds.), North Korea in Transition, Edward Elgar, Cheltenham and Northampton.

Lee Y H (2002) Escaping the poverty trap: North Korea's economic development strategies. East Asian Review 14: 107-121.

Marton A, Mc Gee T and Paterson D G (1995) Northeast Asian economic cooperation and the Tumen River Area Development Project. Pacific Affairs 68: 8-33. 
Ming L (2003) China and the North Korean crisis: facing test and transition. Pacific Affairs 76: $347-373$.

Murphey R (1989) On the evolution of the port city, pp. 223-245 in: Broeze, F (Ed.), Brides of the Sea: Port Cities of Asia from the 16th - 20th Centuries, University of Hawaii Press, Honolulu.

Nam C W and Radulescu D M (2004) Do corporate tax concessions really matter for the success of free economic zones? Economics of Planning 37: 99-123.

Nanto D K and Chanlett-Avery E (2005) The North Korean economy: background and policy analysis. Report for Congress, Congressional Research Service, February $9^{\text {th }}$.

Noland M and Flake G (1997) Opening attempt: North Korea and the Rajin-Sonbong free economic and trade zone. Journal of Asian Business 13: 99-116.

Notteboom T E and Rodrigue J P (2005) Port regionalization: towards a new phase in port development. Maritime Policy and Management 32: 297-313.

Oh J H (2001) Strategies for developing transport infrastructure in North Korea, pp. 215-236 in: Yoon, C H and Lau, L J (Eds.), North Korea in Transition, Edward Elgar, Cheltenham and Northampton.

Park S B (2004) The North Korean economy: current issues and prospects. Carleton Economic Papers, $\mathrm{n}^{\circ}$ 4/5, Carleton University, Department of Economics, Ottawa, Canada.

Rank M (2006) China, NK to open trade zone. North Korea Zone, August 10: http://www.nkzone.org/nkzone/entry/2006/08/10/china_nk_to_ope.php

Roussin S and Ducruet C (2006) Logistic perspectives in DPRK. Proceedings of the Annual Fall Meeting of the Korean Society of Coastal and Ocean Engineers, September 15-16, Seoul, Korea. 
Sandhu H (2003) A doomed reform: North Korea flirts with the free market. Harvard International Review, Spring: 36-39.

Smolensky E and Ratajczak D (1965) The conception of cities. Explorations in Entrepreneurial History 2: 90-131.

Stern E and Hayuth Y (1984) Developmental effects of geopolitically located ports, pp. 239249 in: Hoyle, B S and Hilling, D (Eds), Seaport Systems and Spatial Change, John Wiley, Chilchester.

Takel R E (1974) Industrial Port Development. Scientechnica LTD, Bristol.

The People's Korea (1997a) Information on Entry \& Investment into Rajin-Sonbong District. http://www1.korea-np.co.jp/pk/014th_issue/97102203.htm

The People's Korea (1997b) Contribution of the Rajin-Sonbong Free Economic and Trade Zone to Regional Economic Development in Northeast Asia. http://www1.koreanp.co.jp/pk/032nd_issue/98030405.htm

The People's Korea (1998) Speech by first director of CPEEC. Rason Business Seminar. http://www1.korea-np.co.jp/pk/067th_issue/98102802.htm

Thorez P (1998) Le transport maritime dans les pays issus de l'ex-URSS. Le Courrier des Pays de 1'Est 426: 18-52.

Tsuji H (2003) An international logistical network in Northeast Asia. ERINA Discussion Paper $\mathrm{n}^{\circ}$ 0307e, Economic Research Institute for Northeast Asia, Niigata, Japan, November.

Tsuji H (2005) The transport infrastructure of the DPRK. Working Paper, Economic Research Institute for Northeast Asia, Niigata, Japan.

Tumen River Area Development Programme (2006) Rajin-Sonbong economic and trade zone. DPRK, UNDP: http://www.tumenprogramme.org/tumen/region/rason 
United Nations Development Programme (2006) Economic and investment status in Rason economic and trade development zone. Confidential Document.

Wu J C (2004) The mineral industry of North Korea. U.S. Geological Survey Minerals Yearbook.

Yoon D R (2006) Economic reform and SEZ as survival strategy of DPRK. Korea Institute for International Economic Policy, Seoul. 
Table 1: Official statistics on Raseon's economic performance, 1993-2003

\begin{tabular}{|c|c|c|c|c|c|c|c|c|c|c|c|c|c|c|c|}
\hline \multirow[b]{2}{*}{ Year } & \multicolumn{2}{|c|}{ FDI } & \multicolumn{2}{|c|}{$\begin{array}{c}\text { Firms } \\
\text { start-ups }\end{array}$} & \multicolumn{3}{|c|}{$\begin{array}{c}\text { GDP } \\
\text { (Mil. KRW) }\end{array}$} & \multicolumn{2}{|c|}{$\begin{array}{c}\text { Trade } \\
\text { (Mil. USD) }\end{array}$} & \multicolumn{3}{|c|}{ Tourist flows } & \multicolumn{3}{|c|}{$\begin{array}{c}\text { Port transit traffic } \\
(000 \mathrm{~s})\end{array}$} \\
\hline & 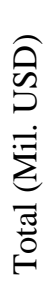 & 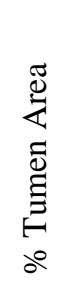 & 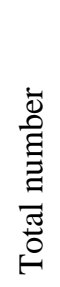 & $\underset{\widehat{\underbrace{}}}{\stackrel{\widetilde{\theta}}{\Xi}}$ & 胥 & 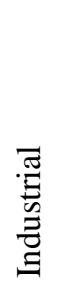 & 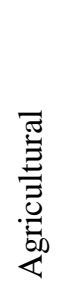 & 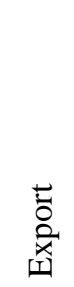 & $\begin{array}{l}\overline{\mathbf{0}} \\
\text { 品 }\end{array}$ & 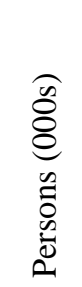 & 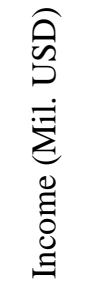 & 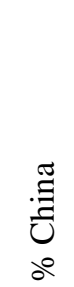 & 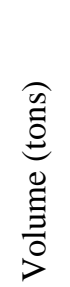 & 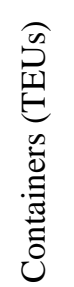 & 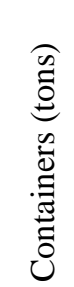 \\
\hline 1993 & 1 & 0.5 & - & - & - & - & - & - & - & - & - & - & - & - & - \\
\hline 1994 & 1 & 1.5 & - & - & 239 & 89 & 46 & 5.8 & 3.9 & - & - & - & - & - & - \\
\hline 1995 & 4 & 2.9 & - & - & 182 & 69 & 37 & 4.9 & 3.4 & 13.5 & 1.83 & 97.5 & - & - & - \\
\hline 1996 & 31 & 11.8 & - & - & 165 & 61 & 23 & 4.8 & 3.1 & 14.8 & 2.62 & 97.5 & 446 & - & - \\
\hline 1997 & 26 & 12.0 & - & - & 154 & 49 & 27 & 5.0 & 3.6 & 17.9 & 2.94 & 98.0 & 248 & - & - \\
\hline 1998 & 25 & 19.5 & 20 & 95 & 155 & 51 & 24 & 4.9 & 3.4 & 18.4 & 3.22 & 98.0 & 240 & - & - \\
\hline 1999 & - & - & 16 & 50 & 826 & - & - & 7.5 & 22.6 & 19.5 & 3.51 & - & 245 & 6.0 & 83.6 \\
\hline 2000 & - & - & 11 & 90 & 913 & - & - & 5.9 & 22.4 & 22.9 & 4.12 & - & 252 & 6.0 & 84.3 \\
\hline 2001 & - & - & 16 & 87 & 1072 & - & - & 13.1 & - & 27.8 & 5.28 & - & 274 & 6.2 & 87.1 \\
\hline 2002 & - & - & 3 & 100 & 1415 & - & - & 9.2 & 15.7 & 35.2 & 6.69 & - & 282 & 6.3 & 87.7 \\
\hline 2003 & - & - & 11 & 72 & 1405 & - & - & 13.4 & 21.7 & 34.1 & 6.50 & - & 290 & 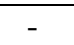 & \\
\hline
\end{tabular}

Source: compiled from United Nations Development Programme (2006)

Table 2: Summary of investments in Raseon, 1996-2004

\begin{tabular}{|c|c|c|c|c|}
\hline Country & \multicolumn{2}{|c|}{ Sector } & $\begin{array}{c}\text { Amount } \\
(000 \text { s USD) }\end{array}$ & $\begin{array}{l}\text { Share } \\
(\%)\end{array}$ \\
\hline \multirow{3}{*}{ China } & \multicolumn{2}{|c|}{$\begin{array}{l}\text { Commerce, services, tourism } \\
\text { Manufacturing }\end{array}$} & 19,518 & \multirow{3}{*}{23.6} \\
\hline & \multirow{2}{*}{\multicolumn{2}{|c|}{$\begin{array}{l}\text { Manufacturing } \\
\text { Transit trade }\end{array}$}} & 17,832 & \\
\hline & & & 3,234 & \\
\hline \multirow{2}{*}{ Japan } & \multicolumn{2}{|c|}{ Seafood processing \& export } & 949 & \multirow[b]{2}{*}{1.8} \\
\hline & \multicolumn{2}{|l|}{ Commercial services } & 2,256 & \\
\hline \multirow{2}{*}{ Hong Kong } & \multicolumn{2}{|l|}{ Hotel \& services } & 59,000 & \multirow[b]{2}{*}{37.1} \\
\hline & \multicolumn{2}{|l|}{ Road construction } & 4,839 & \\
\hline Taiwan & \multicolumn{2}{|l|}{ Tobacco processing } & 2,096 & 1.2 \\
\hline Australia & \multicolumn{2}{|c|}{ Goat farm \& general services } & 1,310 & 0.7 \\
\hline Singapore & \multicolumn{2}{|l|}{ Seafood } & 1,009 & 0.6 \\
\hline Thailand & \multicolumn{2}{|l|}{ Telecom } & 26,880 & 15.6 \\
\hline \multicolumn{3}{|r|}{ Other } & 32,967 & 19.1 \\
\hline & & Total & 171,890 & 100.0 \\
\hline Type & $\begin{array}{l}\text { Number of } \\
\text { businesses }\end{array}$ & $\begin{array}{l}\text { Real investment } \\
\text { rate }(\%)\end{array}$ & $\begin{array}{c}\text { Amount } \\
(000 \text { s USD) }\end{array}$ & $\begin{array}{l}\text { Share } \\
(\%)^{*}\end{array}$ \\
\hline Wholly foreign owned business & 34 & 40 & 85,225 & 100.0 \\
\hline Equity joint venture & 47 & 70 & 27,325 & 50.6 \\
\hline Contractual joint venture & 17 & 33 & 36,392 & 60.9 \\
\hline Local business & 48 & 98 & 22,948 & 0.0 \\
\hline Total & 146 & $45 * *$ & 171,890 & 70.5 \\
\hline
\end{tabular}

Source: compiled from United Nations Development Programme (2006)

* Percentages refer to the share of foreign inflows in each category

** Value refer to average 
Table 3: Urban and port characteristics of Rajin and Seonbong

\begin{tabular}{|c|c|c|c|c|}
\hline & Type & Rajin & Seonbong & $\%$ DPRK \\
\hline \multirow{4}{*}{$\begin{array}{l}\text { Number of housing } \\
\text { units }\end{array}$} & Rural type housing (1 floor) & 348 & 458 & 6.5 \\
\hline & Low density housing (2-3 floors) & 504 & 509 & 6.7 \\
\hline & High density housing (5-6 floors) & 145 & 115 & 3.7 \\
\hline & Total & 997 & 1,082 & 6.0 \\
\hline \multirow{6}{*}{$\begin{array}{l}\text { Spatial distribution } \\
\text { of housing units } \\
(\%)\end{array}$} & City centre & 36.1 & 28.6 & 5.0 \\
\hline & $2 \mathrm{~km}$ & 49.2 & 33.5 & 3.6 \\
\hline & $4 \mathrm{~km}$ & 6.6 & 20.6 & 0.9 \\
\hline & $6 \mathrm{~km}$ & 8.0 & 10.4 & 1.8 \\
\hline & $8 \mathrm{~km}$ & 0.0 & 6.9 & 1.2 \\
\hline & Total & 100.0 & 100.0 & 6.0 \\
\hline \multirow{2}{*}{ Population } & Official (2005) & 77,000 & 27,000 & 4.1 \\
\hline & Estimated (1997) & 64,912 & 18,912 & 5.2 \\
\hline \multirow{2}{*}{$\begin{array}{l}\text { Potential industrial } \\
\text { sites }\left(\mathrm{km}^{2}\right)\end{array}$} & \multirow{2}{*}{$\begin{array}{l}\text { Inner city } \\
\text { Total }\end{array}$} & 5.8 & 12.4 & 30.1 \\
\hline & & 8.6 & 24.4 & 9.2 \\
\hline \multirow{2}{*}{ Quay length (m) } & Minima & 2,280 & 456 & 26.3 \\
\hline & Maxima & 4,340 & 2,515 & 24.7 \\
\hline \multirow{2}{*}{ Quay depth (m)* } & Minima & 10 & 7 & 13.2 \\
\hline & Maxima & 11 & 23 & 8.1 \\
\hline Handling facilities & Number of quay cranes & 1 & 0 & 0.3 \\
\hline \multirow{3}{*}{$\begin{array}{l}\text { Capacity } \\
(000 \text { s tons })\end{array}$} & Stevedoring & 3,000 & 2,000 & 16.9 \\
\hline & Berth & 15 & 5 & 16.6 \\
\hline & Traffic & 3,225 & 3,710 & 19.8 \\
\hline \multicolumn{2}{|c|}{$\begin{array}{l}\text { Port-city relative concentration index } \\
\text { (\% traffic capacity / \% population) }\end{array}$} & 3.0 & 10.0 & 4.9 \\
\hline
\end{tabular}

Source: Asia Trade Hub (2006); Atlas of North Korea (1997); Helders (2006)

* DPRK value refer to country average 
Table 4: Advantages and constraints of the Raseon FTZ

\begin{tabular}{|c|c|c|}
\hline & Constraints & Advantages \\
\hline 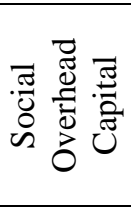 & $\begin{array}{l}* \text { Isolation and lack of facilities } \\
* \text { Precedence of geo-political logic over geo- } \\
\text { economic logic causing poor performance } \\
* \text { Lack of knowledge and management skills }\end{array}$ & $\begin{array}{l}* \text { Border trade and potential for DPRK's } \\
\text { balanced development } \\
\text { * Potential integration to Europe-Asia land bridge } \\
\text { * Regular training sessions of DPRK officials } \\
\text { about capitalist economy }\end{array}$ \\
\hline 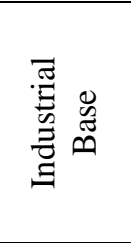 & $\begin{array}{l}\text { Unattractive industry to foreign investors } \\
\text { (backwardness, outdated industrial technology } \\
\text { and skills, lack of energy and raw materials to } \\
\text { run the plants, logistics costs for distribution of } \\
\text { finished products) }\end{array}$ & $\begin{array}{l}\text { * Economic diversity: seafood, food processing, } \\
\text { construction, real estate, tourism, transport, } \\
\text { energy, oil refinery, chemicals } \\
\text { * Large traditional mining area (iron, coal, } \\
\text { copper) and raw material natural resources } \\
\text { (timber, gravel, sand) }\end{array}$ \\
\hline 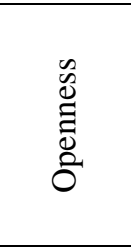 & $\begin{array}{l}\text { * Unstable attitude of DPRK's regime towards the } \\
\text { outside world (e.g. investment protection } \\
\text { treaties) } \\
\text { * Juche ideology and protectionism } \\
* \text { Confidentiality of DPRK practices to hamper } \\
\text { inter-port regional cooperation }\end{array}$ & $\begin{array}{l}\text { Income tax exemption to foreign firms: } \\
* 14 \% \text { in general and } 10 \% \text { for certain high-tech } \\
\text { activities } \\
* 50 \% \text { to } 100 \% \text { during the } 3 \text { years following first } \\
\text { profit within } 10 \text {-years operation }\end{array}$ \\
\hline 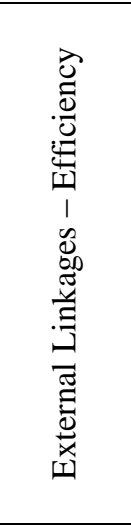 & $\begin{array}{l}* \text { Remoteness from DPRK's core region (19h by } \\
\text { train, out of reach by road) } \\
* \text { Frequent truck accidents in northern mountainous } \\
\text { and coastal roads } \\
* \text { Absence of tunnels to reach Wonjong } \\
* \text { Only } 10 \% \text { of port capacity in operation } \\
* \text { Outdated port infrastructures } \\
* \text { Absence of a close core economic center like Hong } \\
\text { Kong } \\
* \text { Absence of air transport linkages } \\
* \text { Isolation from neighbouring bigger ports } \\
* \text { Transit trade caught by rival Russian ports due to } \\
\text { lack of capacity and poor infrastructure }\end{array}$ & $\begin{array}{l}\text { * Highway development to link Hunchen city } \\
\text { * Only ice-free port in the region, good nautical } \\
\text { accessibility } \\
\text { * Mixed standard and broad gauges (Russian } \\
\text { standard) for railways } \\
\text { * Improved road connection to Jilin province via } \\
\text { Wonjong free market ( } 50 \mathrm{~km}) \\
\text { * Express cargo train between Rajin and } \\
\text { Namyang (1997) } \\
\text { * Opening of new container lines projected by } \\
\text { the inter-Korean maritime agreement }(2004)\end{array}$ \\
\hline 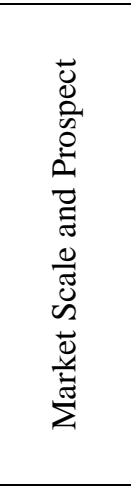 & $\begin{array}{l}\text { * Small population of } 150,000 \text { inhabitants } \\
* \text { Limited workforce basin; recruitment is regulated } \\
\text { by DPRK and restricted geographically } \\
\text { * Scarcity of land for new industrial areas (forests, } \\
\text { swamps, lakes, mountains } 75 \% \text {, cultivated } 13 \% \text {, } \\
\text { water } 7.5 \% \text {, industrial } 2.5 \% \text {, residential } 2 \% \text { ) }\end{array}$ & $\begin{array}{l}\text { * Over } 50 \% \text { of investments to transportation and } \\
\text { tourism between } 1992 \text { and } 1996 \\
* \text { Project of a logistics free-zone at Namyang for } \\
\text { China, ROK and Japan companies } \\
\text { * Leasing and development of container terminals } \\
\text { to China for } 25-80 \text { years for transit trade } \\
\text { * Raseon International Logistics Joint Company } \\
\text { created in } 2005 \text { with exclusive rights to run } 3^{\text {rd }} \\
\text { and } 4^{\text {th }} \text { piers of Rajin port for } 50 \text { years } \\
\text { * Industrial park of 5-10 sq km from Chinese } \\
\text { investment (36 million USD) with tourism and } \\
\text { road facilities underway }\end{array}$ \\
\hline 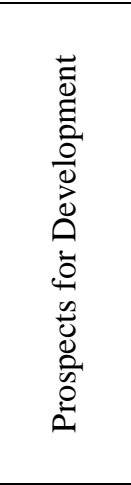 & $\begin{array}{l}\text { * Persistence of a "Soviet model" of economic } \\
\text { development - preference to heavy industries } \\
\text { and lack of investment in transport and logistics } \\
\text { * Historical antagonism since Japanese occupation } \\
\text { harming regional cooperation } \\
\text { * Competition from other North Korean zones and } \\
\text { existing Asian export platforms offering low } \\
\text { wages and high investment incentives } \\
\text { * Local - regional - national negative multiplier } \\
\text { effects within DPRK } \\
\text { * Trade embargo from the US, UN sanctions } \\
\text { against nuclear tests }\end{array}$ & $\begin{array}{l}\text { * Part of the UNDP project for Tumen River } \\
\text { Area Development Program since } 1992 \\
\text { * Positive experience of Gaeseong Industrial } \\
\text { Park financed by South Korea and growing } \\
\text { since } 2004 \text { (10,000 workers in } 15 \text { companies } \\
\text { in 2006) } \\
\text { * Failure of Sinuiju SAR due to politics despite a } \\
\text { more favourable environment than Raseon } \\
\text { * Economic reforms applied to the entire } \\
\text { economy since July } 2002 \\
\text { * Restart of the 6-party talks since Feb. } 2007\end{array}$ \\
\hline
\end{tabular}

Source: adapted from Kim (2000) and various sources 
Table 5: North Korean foreign trade, 1991-2005 (Unit: million US\$)

\begin{tabular}{|c|c|c|c|c|c|c|c|c|c|c|c|c|c|c|c|c|}
\hline & 1991 & 1992 & 1993 & 1994 & 1995 & 1996 & 1997 & 1998 & 1999 & 2000 & 2001 & 2002 & 2003 & 2004 & 2005 \\
\hline \multicolumn{2}{|c|}{ China, of which : } & 650 & 697 & 899 & 624 & 550 & 609 & 650 & 410 & 370 & 480 & 737 & 738 & 1024 & 1377 & 1580 \\
\hline \multicolumn{2}{|l|}{ Export } & 86 & 156 & 297 & 199 & 64 & 62 & 120 & 60 & 50 & 30 & 167 & 271 & 396 & 582 & 499 \\
\hline \multicolumn{2}{|l|}{ Import } & 525 & 541 & 602 & 425 & 486 & 547 & 530 & 350 & 320 & 450 & 571 & 467 & 628 & 795 & 1081 \\
\hline \multicolumn{2}{|l|}{ General trade } & - & - & - & - & - & - & - & - & - & - & - & - & 452 & 641 & 826 \\
\hline \multicolumn{2}{|c|}{$\begin{array}{l}\text { Processing on } \\
\text { commission trade }\end{array}$} & - & - & - & - & - & - & - & - & - & - & - & - & 55 & 57 & 73 \\
\hline \multicolumn{2}{|l|}{ Border trade } & - & - & 304 & - & - & - & 210 & 130 & 100 & 130 & 369 & 352 & 196 & 300 & 441 \\
\hline \multicolumn{2}{|c|}{ Bonded area trade } & - & - & - & - & - & - & - & - & - & - & - & - & 299 & 342 & 180 \\
\hline \multicolumn{2}{|l|}{ Aid } & - & - & - & - & - & - & - & - & - & - & - & - & 11 & 15 & 38 \\
\hline \multicolumn{2}{|l|}{ Others } & - & - & - & - & - & - & - & - & - & - & - & - & 10 & 22 & 22 \\
\hline \multicolumn{2}{|c|}{$\begin{array}{l}\text { North Hamgyeong } \\
\text { province }\end{array}$} & 97 & 218 & 471 & 454 & 150 & 116 & 105 & - & - & - & - & - & - & - & - \\
\hline \multicolumn{2}{|c|}{$\%$ DPRK trade } & 3.7 & 8.5 & 17.8 & 21.6 & 7.3 & 5.8 & 4.8 & - & - & - & - & - & - & - & - \\
\hline \multicolumn{2}{|c|}{ Export to China } & 48 & 98 & 229 & 250 & 89 & 76 & 37 & - & - & - & - & - & - & - & - \\
\hline \multicolumn{2}{|c|}{ Import from China } & 44 & 120 & 242 & 204 & 61 & 40 & 24 & - & - & - & - & - & - & - & - \\
\hline \multirow{2}{*}{$\begin{array}{l}\text { Jilin } \\
\text { province* }\end{array}$} & Import & - & - & - & - & - & - & - & 41.2 & 47.6 & 48.6 & 15.0 & 12.5 & 12.4 & 18.0 & 20.7 \\
\hline & Export & - & - & - & - & - & - & - & 19.3 & 17.0 & 20.8 & 24.2 & 23.8 & 25.5 & 25.7 & 22.6 \\
\hline \multirow{2}{*}{$\begin{array}{l}\text { Liaoning } \\
\text { province }\end{array}$} & Import & - & - & - & - & - & - & - & 43.1 & 42.9 & 40.5 & 67.7 & 80.4 & 81.6 & 66.8 & 48.9 \\
\hline & Export & - & - & - & - & - & - & - & 37.5 & 36.2 & 31.9 & 30.3 & 28.9 & 24.5 & 26.0 & 29.9 \\
\hline \multirow{2}{*}{$\begin{array}{l}\text { Heilongjiang } \\
\text { province }\end{array}$} & Import & - & - & - & - & - & - & - & 3.9 & 0.0 & 0.0 & 0.6 & 0.7 & 0.0 & 0.5 & 1.6 \\
\hline & Export & - & - & - & - & - & - & - & 12.9 & 15.2 & 16.0 & 16.1 & 17.6 & 15.6 & 11.9 & 12.7 \\
\hline \multicolumn{2}{|l|}{ South Korea } & 111 & 173 & 187 & 195 & 287 & 252 & 308 & 251 & 310 & 425 & 403 & 642 & 724 & 697 & 1056 \\
\hline \multicolumn{2}{|l|}{ Russia } & 365 & 312 & 222 & 95 & 85 & 65 & 85 & 65 & 56 & 46 & 68 & 80 & 118 & 213 & 232 \\
\hline \multicolumn{2}{|l|}{ Japan } & 508 & 482 & 472 & 494 & 595 & 518 & - & 439 & 337 & 426 & 474 & 369 & 265 & 252 & 194 \\
\hline \multicolumn{2}{|c|}{ Southeast Asia } & - & - & - & - & - & - & - & - & - & - & 287 & 407 & 412 & 520 & 409 \\
\hline \multicolumn{2}{|l|}{ EU countries } & - & - & - & - & - & - & - & - & - & - & - & - & - & 261 & 292 \\
\hline \multicolumn{2}{|l|}{ Others } & - & - & - & - & - & - & - & - & - & - & 702 & 633 & 572 & 226 & 294 \\
\hline \multicolumn{2}{|l|}{ Total } & 2584 & 2555 & 2646 & 2100 & 2052 & 1976 & 2177 & 1442 & 1480 & 1970 & 2673 & 2902 & 3115 & 3554 & 4045 \\
\hline
\end{tabular}

Sources: KOTRA, Ministry of Unification, Kim (2001), Dunqiu (2006), Yoon (2006)

* Trade figures with Chinese provinces represent the share (\%) in total DPRK imports or exports with China 
Table 6: Seaborne activity of Rajin port, 1985-2005 (Unit: 000s DWT unless indicated)

\begin{tabular}{|c|c|c|c|c|c|c|c|c|c|c|c|c|c|c|c|c|c|c|c|c|c|}
\hline & $\stackrel{\circ}{\varrho}$ & $\stackrel{\circ}{2}$ & $\stackrel{\circ}{\circ}$ & $\stackrel{\infty}{\circ}$ & ळे & बे & $\bar{\sigma}$ & $\tilde{\sigma}$ & ڤิ & 亏ั & $\stackrel{2}{2}$ & 亏ั & $\hat{\sigma}$ & $\stackrel{\circ}{2}$ & बे & હิે & อิ & ฮิ่ & 气ิે & ఫิે & 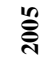 \\
\hline Total & 243 & 281 & 451 & 261 & 168 & 68 & 273 & 754 & 368 & 340 & 70 & 22 & 83 & 20 & 42 & 133 & 61 & 65 & 133 & 117 & 149 \\
\hline$\%$ DPRK & 3.1 & 3.2 & 5.5 & 3.9 & 2.5 & 1.0 & 4.1 & 17.1 & 9.1 & 7.4 & 1.8 & 0.5 & 1.6 & 0.5 & 0.7 & 2.2 & 0.9 & 1.8 & 3.3 & 3.3 & 2.4 \\
\hline$\%$ East coast & 4.6 & 5.0 & 9.3 & 7.2 & 5.1 & 2.1 & 9.6 & 37.6 & 20.1 & 19.1 & 5.2 & 2.0 & 6.1 & 2.4 & 1.7 & 5.8 & 2.4 & 6.1 & 12.8 & 15.0 & 10.8 \\
\hline China & 0 & 29 & 120 & 136 & 57 & 32 & 13 & 85 & 6 & 56 & 17 & 10 & 0 & 0 & 0 & 0 & 0 & 0 & 0 & 8 & 0 \\
\hline Japan & 178 & 186 & 256 & 60 & 101 & 28 & 225 & 573 & 191 & 46 & 29 & 0 & 53 & 14 & 32 & 109 & 43 & 40 & 51 & 13 & 48 \\
\hline ROK & 0 & 0 & 0 & 0 & 7 & 0 & 14 & 25 & 6 & 18 & 0 & 12 & 0 & 6 & 6 & 11 & 12 & 1 & 0 & 6 & 0 \\
\hline Russia & 19 & 56 & 44 & 36 & 3 & 0 & 21 & 20 & 160 & 0 & 0 & 0 & 14 & 0 & 3 & 13 & 6 & 19 & 50 & 89 & 101 \\
\hline SE Asia & 13 & 0 & 0 & 29 & 0 & 8 & 0 & 36 & 0 & 150 & 24 & 0 & 16 & 0 & 0 & 0 & 0 & 0 & 31 & 0 & 0 \\
\hline Other & 34 & 11 & 31 & 0 & 0 & 0 & 0 & 14 & 5 & 70 & 0 & 0 & 0 & 0 & 0 & 0 & 0 & 5 & 0 & 0 & 0 \\
\hline $\begin{array}{l}\text { General } \\
\text { Cargo }\end{array}$ & 102 & 141 & 208 & 111 & 32 & 9 & 102 & 259 & 27 & 13 & 11 & 16 & 24 & 10 & 19 & 64 & 29 & 13 & 63 & 52 & 6 \\
\hline $\begin{array}{l}\text { Container \& } \\
\text { Ro-Ro }\end{array}$ & 0 & 0 & 0 & 23 & 17 & 12 & 0 & 0 & 28 & 0 & 0 & 0 & 0 & 0 & 0 & 2 & 1 & 2 & 2 & 14 & 50 \\
\hline Solid Bulks & 28 & 0 & 34 & 0 & 34 & 14 & 42 & 125 & 129 & 157 & 24 & 0 & 14 & 0 & 0 & 0 & 0 & 16 & 0 & 0 & 18 \\
\hline Liquid Bulks & 0 & 0 & 0 & 6 & 0 & 0 & 0 & 0 & 0 & 0 & 0 & 0 & 0 & 0 & 1 & 0 & 0 & 0 & 2 & 0 & 0 \\
\hline $\mathrm{Nb}$. ships & 18 & 23 & 29 & 24 & 10 & 5 & 18 & 33 & 16 & 7 & 3 & 2 & 6 & 2 & 5 & 14 & 8 & 12 & 25 & 34 & 39 \\
\hline$\%$ DPRK & 4.7 & 5.6 & 8.3 & 7.1 & 3.0 & 1.6 & 5.4 & 12.5 & 7.2 & 2.7 & 1.5 & 0.7 & 1.3 & 0.6 & 1.4 & 3.7 & 2.0 & 3.5 & 5.6 & 7.4 & 5.0 \\
\hline$<4499$ & 5 & 3 & 4 & 0 & 2 & 1 & 0 & 4 & 0 & 1 & 0 & 0 & 1 & 1 & 4 & 12 & 7 & 11 & 21 & 32 & 37 \\
\hline$<14999$ & 13 & 20 & 20 & 23 & 7 & 4 & 16 & 28 & 14 & 3 & 2 & 2 & 5 & 1 & 1 & 1 & 1 & 0 & 3 & 2 & 1 \\
\hline$<50000$ & 0 & 0 & 5 & 1 & 1 & 0 & 2 & 1 & 2 & 3 & 1 & 0 & 0 & 0 & 0 & 1 & 0 & 1 & 1 & 0 & 1 \\
\hline TEUs & 368 & 112 & 165 & 436 & 150 & 336 & 1830 & 587 & 3118 & 0 & 562 & 0 & 422 & 0 & 300 & 1053 & 438 & 0 & 748 & 165 & 165 \\
\hline$\%$ DPRK & 5.2 & 1.1 & 1.4 & 4.0 & 1.7 & 2.4 & 14.7 & 5.4 & 37.7 & 0.0 & 8.2 & 0.0 & 6.6 & 0.0 & 2.5 & 12.2 & 3.0 & 0.0 & 4.7 & 0.8 & 0.9 \\
\hline
\end{tabular}

Source: Lloyd's Marine Intelligence Unit 
Figure 1: A matrix of centrality and intermediacy applied to port cities

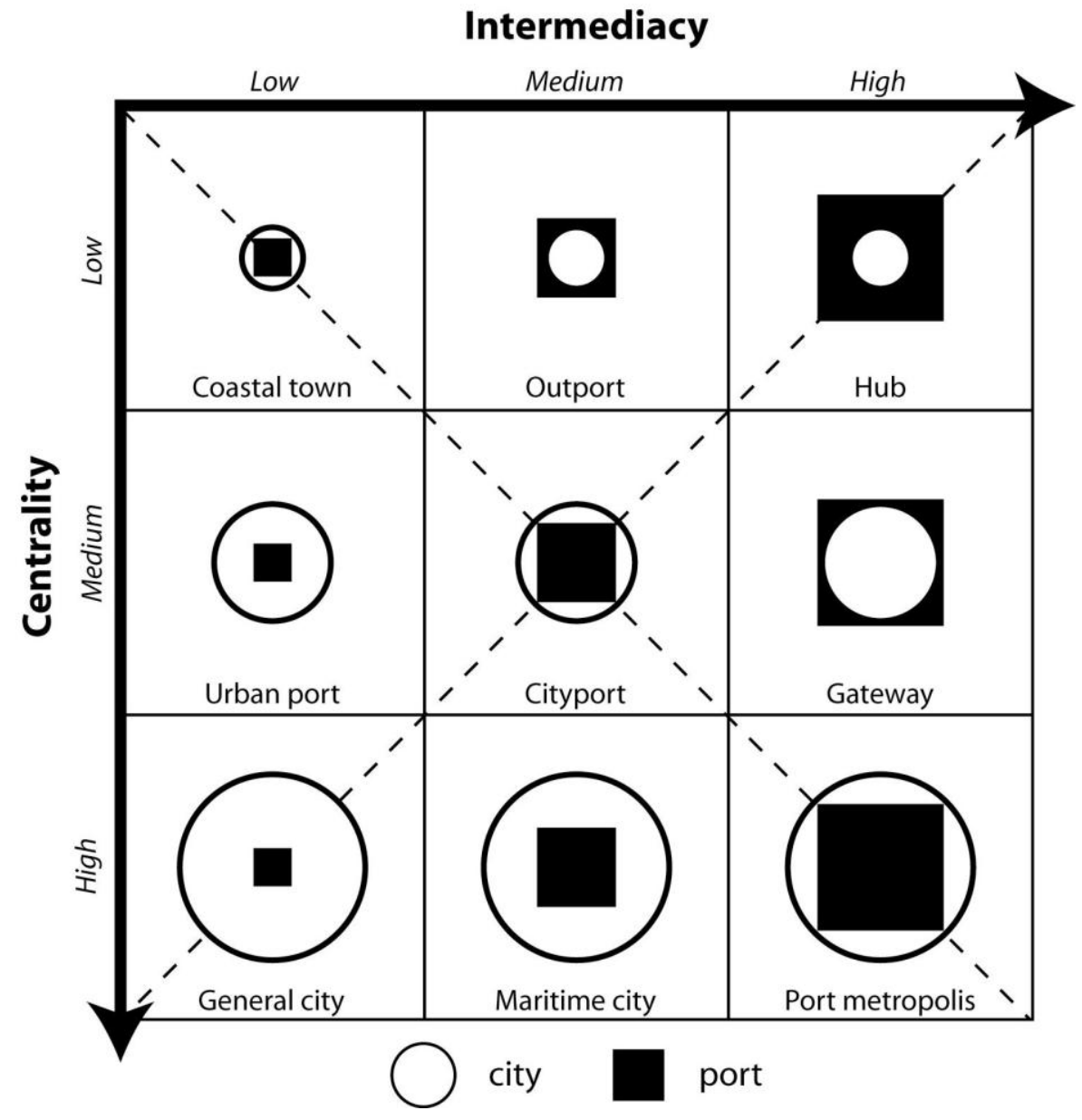

Source: modified from C. Ducruet, 2004 
Figure 2: The North Korean transport system

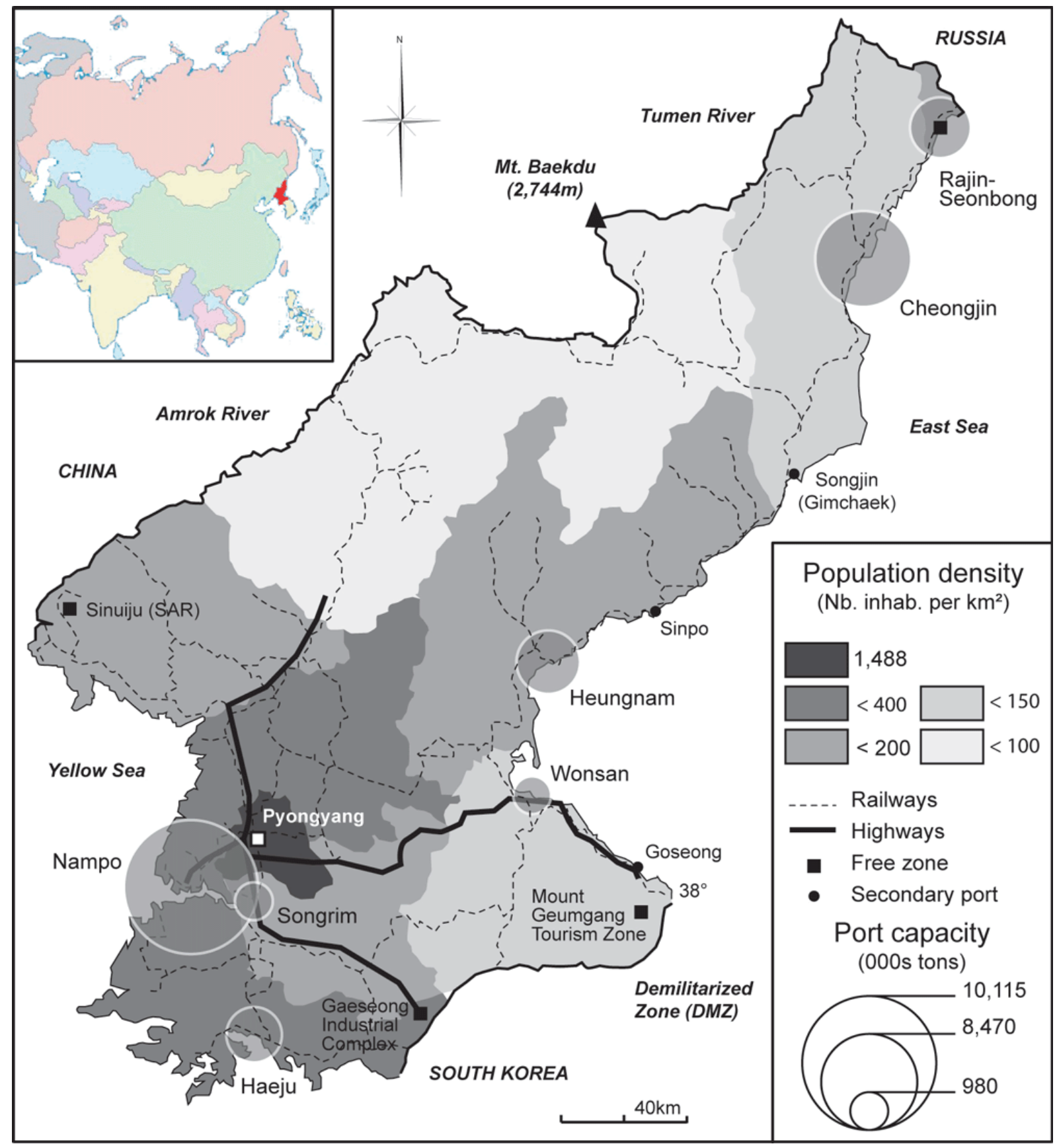

Source: compiled from various sources 
Figure 3: Spatial organization and industrial potentials of Rajin and Seonbong city-regions

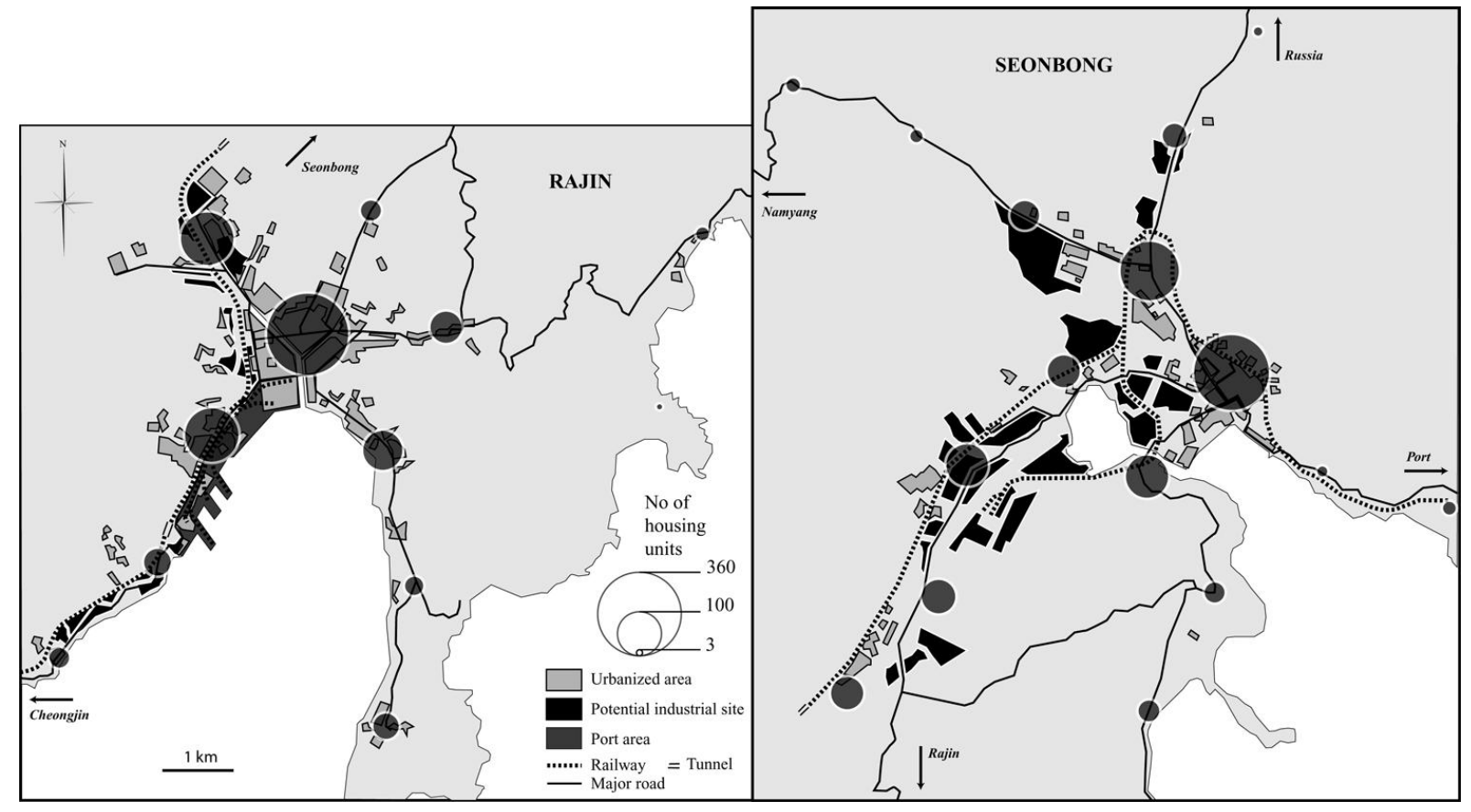

Source: modified from Atlas of North Korea (1997)

Figure 4: Population evolution by province and city

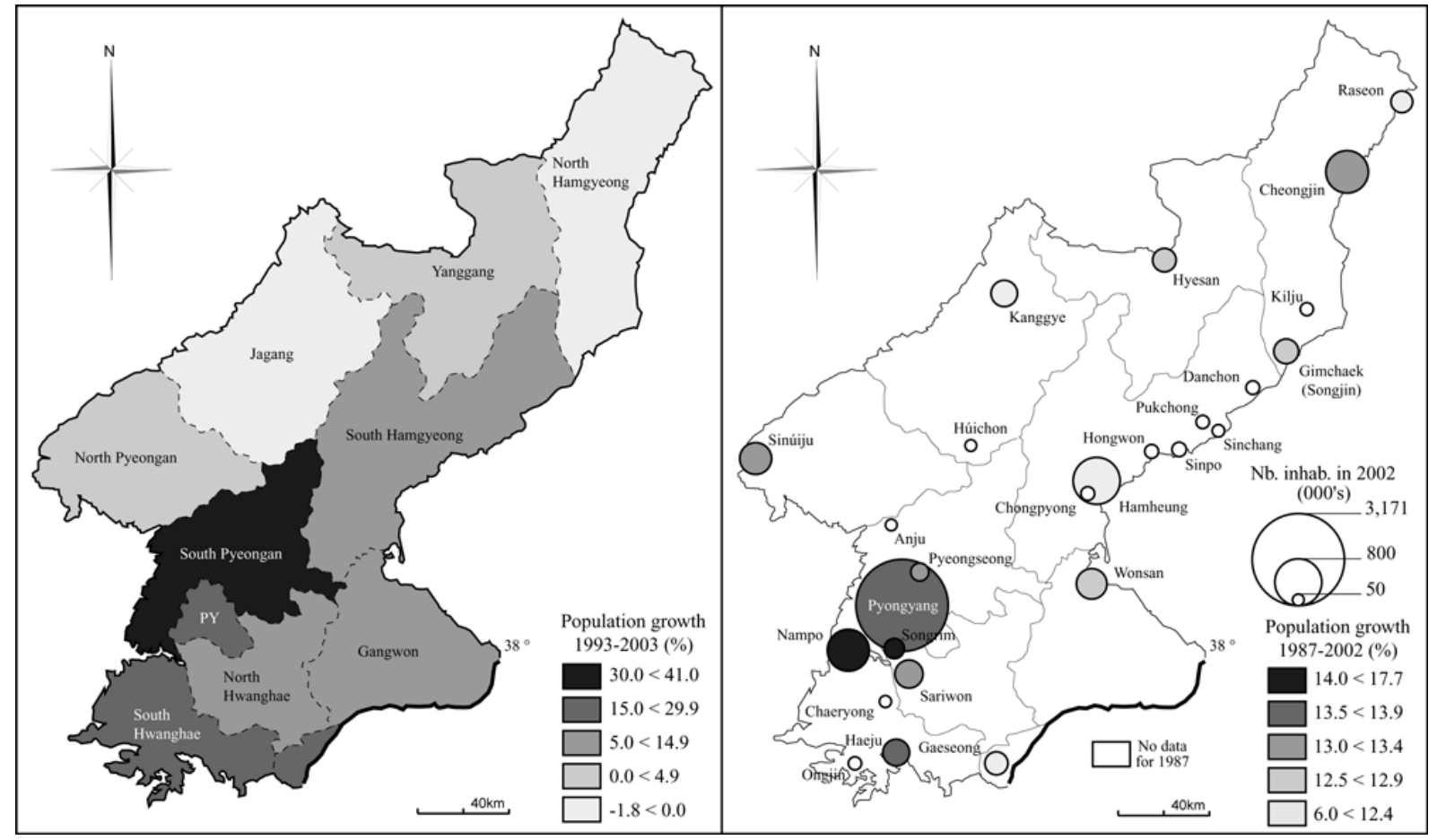

Source: Jo and Adler (2002); Helders (2006) 
Figure 5: Maritime trade between North and South Korea in 2000

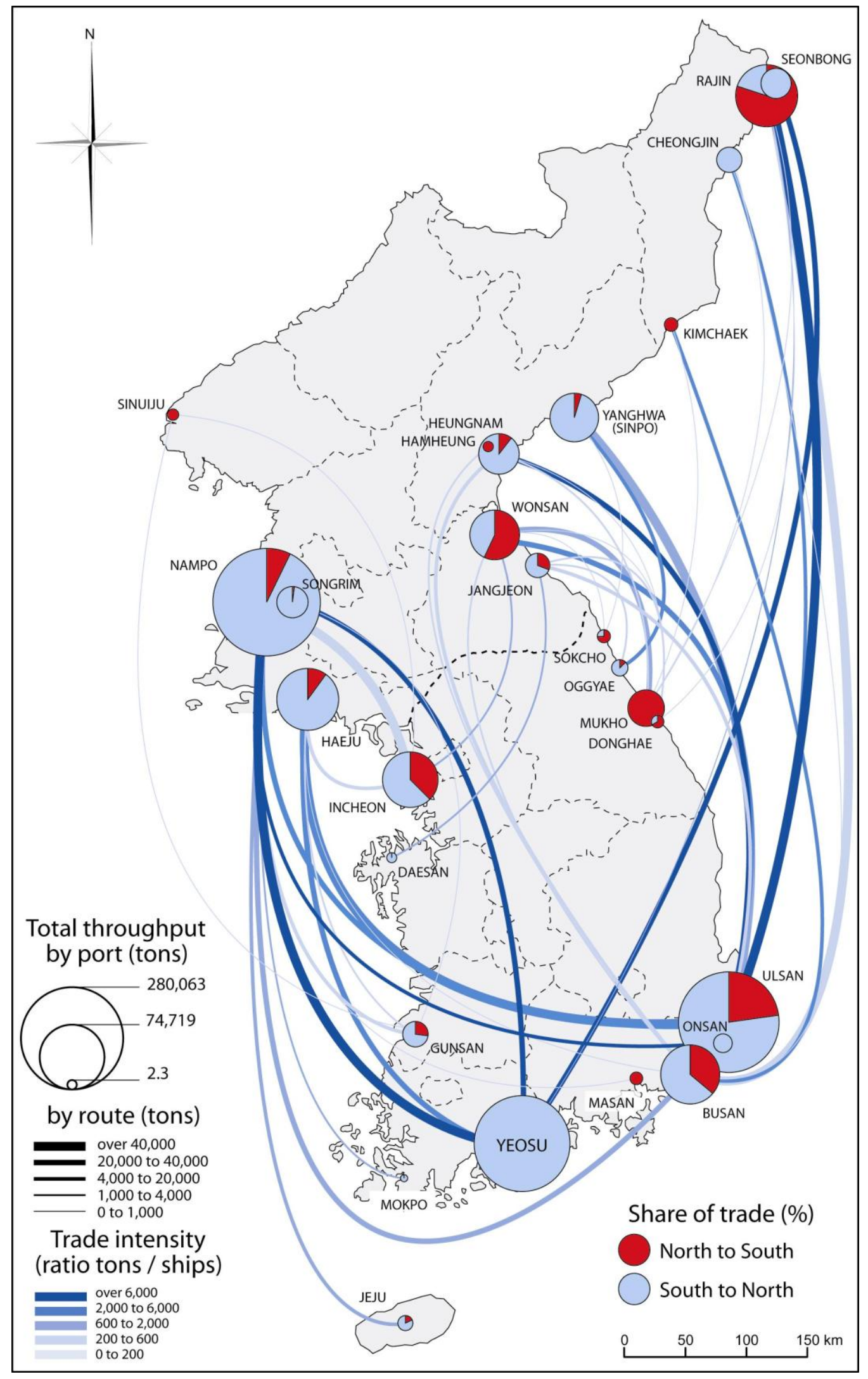

Source: Ministry of Unification in South Korea 
Figure 6: Regional distribution of Rajin port's foreland by port and period, 1985-2005

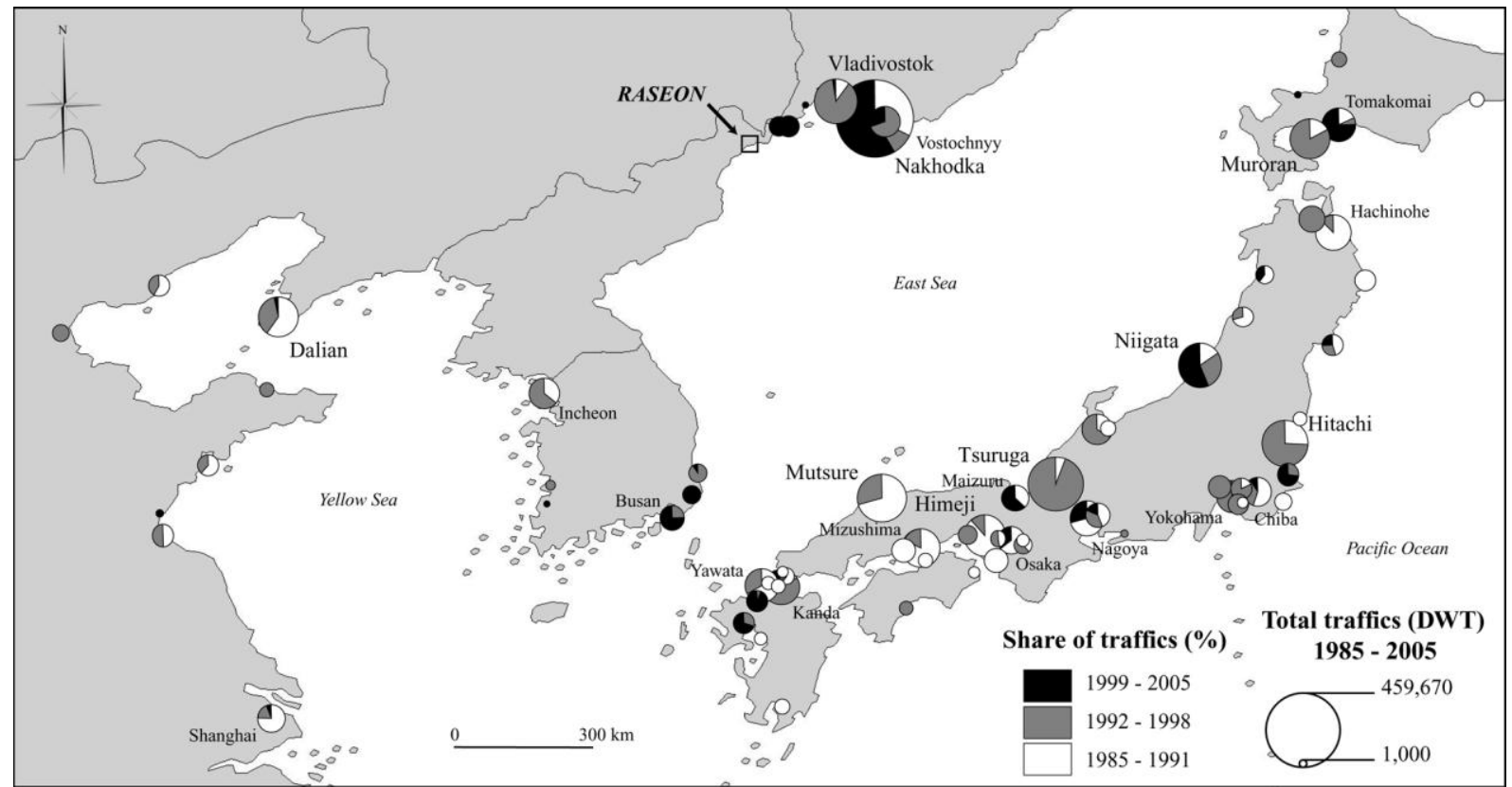

Source: Lloyd's Marine Intelligence Unit 